\title{
ハロゲンフリーエポキシドの実用的合成法
}

松田

\section{Practical Synthetic Method for Halogen-free Epoxides}

Yutaka Matsuda

Halogen-free epoxides are great demand for the recent "Green chemistry". In this short review, I described the recent chemical epoxidation without halogen compounds. Additionally, several remarkable examples of enzymatic epoxidation also are introduced.

エポキシドは有機合成における重要化合物である。機 能性高分子や医薬品中間体など多くの用途があるが，そ のなかでも産業的な観点から注目したいのがエポキシ樹 脂である。例えば，電子材料用途においてのエポキシ樹 脂は，ハンドリングのしやすさ，得られる硬化物の優れ た耐候性や絶縁特性, 無機フィラーとの良好な密着性と いった特徴から重宝されている。

エポキシ樹脂を合成する一般的な方法は, エピクロロ

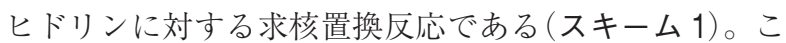
の際，エポキシドへの副反応も進行してしまい，多くの 塩素含有化合物が同時に生成してしまう。この塩素含有 の副生成物は数百 $\mathrm{ppm}$ オーダーでも電気特性に悪影響 を及ぼすため, エポキシ樹脂の含有塩素量を低減させる ことは長年の課題であった。一方，スマートフォンやパ ソコンは近年ますます小型化が進んでおり，それに伴い 材料に求められる機能もより高度化し，できる限り「塩 素を含まない」エポキシ樹脂には強いニーズがある。ま た，コスト面を考えると精製工程も簡略化が望まれるた め,「いかに合成段階で副反応を抑えるか」が電子材料用 途のエポキシ樹脂の鍵となっている。
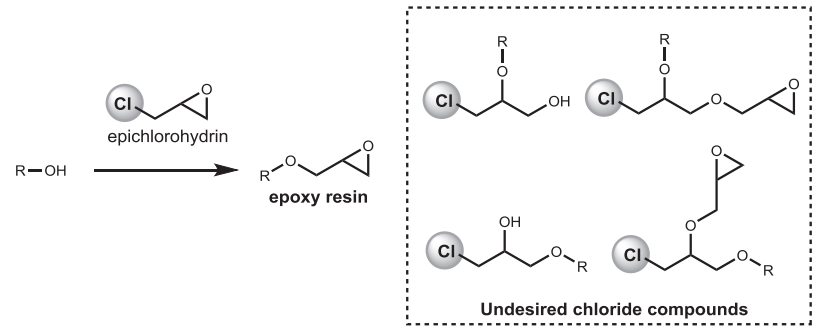

Scheme 1 Epichlorohydrin method.

また，医薬用途においてエポキシドはキラルシントン として利用価值が高く，低分子医薬品に合成の中間体と して利用されているケースは少なくない。光学活性エポ キシドの合成法は Sharpless 不斉エポキシ化など，信頼
性の高い反応が多くあるものの, 重金属触媒の使用や塩 素系溶媒を使用するケースが多く, 環境負荷の点から課 題がある。

そういった背景のなか, 本稿では原料や中間体に「塩 素を用いることのない」環境調和型のエポキシド合成法 について紹介する。

有機合成化学協会誌の読者の方々にとって, エポキシ 化は「目新しさのない反応」であると思う。しかし，その ような「当たり前の反応」であってもブレイクスルーの余 地は残っており，産業界の役に立つことがあるというこ とを読者の方々に感じていただければ幸いである。

\section{1. タングステン触媒と過酸化水素を用いた酸化法}

過酸化水素は副生成物が水のみというクリーンな酸化 剂であり，金属触媒と組み合わせる酸化反応は古くから 知られている。そのなかでも, タングステンは高い反応 活性と低い過酸化水素分解能を併せ持つ金属触媒として 注目されていた。1996 年, 佐藤, 野依らはタングステン 触媒と過酸化水素による酸化反応を，有機溶媒を使わな い低環境負荷な条件で行い, 高収率でエポキシドを合成 した スキーム2) $)^{1)}$ 。

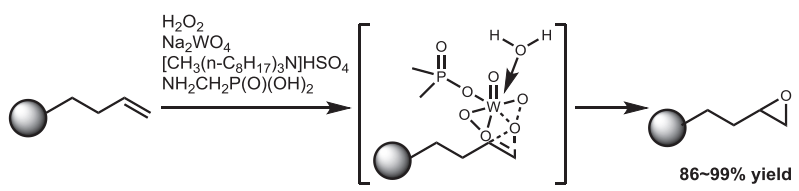

Scheme 2 Tungsten-catalyzed epoxidation.

本反応は, 二相系で進行し, かつ様々な添加剤が関与 する複雑な反応機構であることが知られているが2)，本 稿では誌面の都合上，非常に簡略化して記載している。 まず，水相でタングステン酸ナトリウムと過酸化水素が 反応し, 過酸化物の活性種が生じる。続いて, 活性種と 相間移動触媒である硫酸アンモニウムとペアを作り，原 料であるオレフィンが存在する有機相へと運ばれる。活 
性種によりエポキシ化が進行した後, 酸素原子を失った タングステン触媒は再び水相に戻った後, 再酸化される という触媒サイクルが提唱されている。また, 詳細は明 らかになっていないが, アミノメチルホスホン酸は添加 することで反応が促進されることから，タングステン触 媒に配位し活性化していると考えられている。

タングステン-過酸化水素系の酸化反応は既に工業化 に成功している。産業総合研究所と昭和電工のグループ は，ビフェニル型エポキシ樹脂である TMBDG $(3,3,5,5$ テトラメチルビフェニル-4,4-ジオールジグリシジル エーテル)の実用的合成手法を報告した (図 1) ${ }^{3)}$ 。

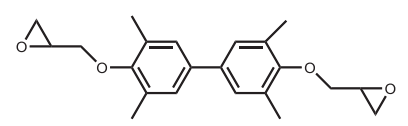

Fig. 1 TMBDG-type Shofree ${ }^{\circledR}$ epoxy resin.

ビフェニル型エポキシ樹脂は常温では結晶であるもの の, 溶融した際には液状樹脂なみの低粘度になるという ユニークな特性をもち, 半導体封止材などの電子材料分 野で幅広く用いられている。過酸化水素酸法で合成した TMBDG は含有塩素量が大変少量であり (2 ppm 程度),

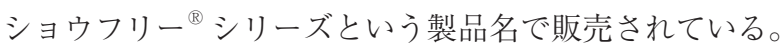

\section{2. スチレンモノオキシゲナーゼ (SMO) を用いた酵素的 酸化}

前述の過酸化水素法は非常に効果的な合成方法である 反面, 課題もある。第一に安全性は高いながらも過酸に よる反応であるため, リスクアセスメントの観点でより 安全なプロセスにできることが望ましい。第二に, 反応 機構が複雑であるため, 不斉合成への応用が難しいこと があげられる。これらを解決できうるのが酵素による “Bio-epoxidation”である。生体内ではチトクローム P450 やスチレンモノオキシゲナーゼ (SMO) などが, 酸 化反応によって疎水的な異物に親水性を付与させて代謝 させている。一般的に，これらの酵素反応は低環境負荷 で安全性が高く, 立体選択的に進行し光学活性なエポキ シドを与えることから, 精力的に研究されている。

特に注目したいのが, SMOによる不斉エポキシ化プロ セスである。SMO は発現する菌種によってはスチレン以 外のオレフィンも酸化することから, 基質許容性の高い 酵素であるといえる。例えば, 伊藤らはRhodococcus sp. ST-10より取得した SMO による酸化反応プロセスに着 目し，各種スチレン誘導体だけでなく，近年では比較的 不活性であると考えられていた直鎖オレフィンにまで応 用し, 光学活性なエポキシド生産に成功している(図 2) ${ }^{4)}$ 。

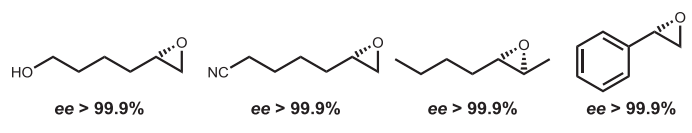

また, SMO のエポキシ化がオレフィン近傍の水酸基 によって加速されることを利用し，Wuらはラセミのア リルアルコールに対し，E. coli から発現させたリコン ビナントの SMO を用いてアリルアルコールの速度論的 分割を行った $(\text { スキーム3 })^{5)}$ 。

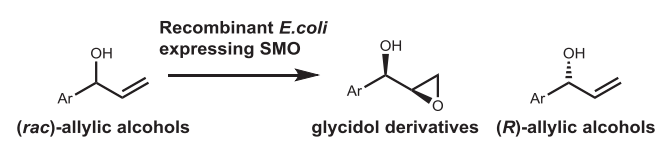

Scheme 3 Kinetic resolution by SMO.

また, protein engineeringによるSMO の改変も多く の試みがなされている。2010 年にPseudomonas putida S-12 由来 SMO のサブユニットの結晶構造解析が報告 されたことをきっかけに $(\mathrm{PDB}: 3 \mathrm{IHM})^{6)}$ ， ドッキング計 算によって SMO のスチレン認識部位のアミノ酸配列が 明らかになった。その知見をべースにスチレン認識部位 のアミノ酸残基を変異させたものが産生され，そのうち S96A 変異型は野生型よりも高い酵素活性と光学収率を 達成した7)。

\section{おわりに}

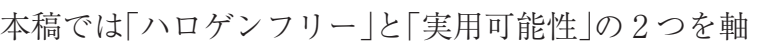
に，エポキシド合成について述べた。実用化という目線 で見れば，ケミカル的な合成法が一歩リードしているよ うに見えるが，酵素法は不斉合成という観点で大変魅力 的である。効率的かつ堅牢な合成プロセスの確立は, 化 合物製造のトータルコストを抑えることにもつながる。 今後も「ケミカル」と「バイオ」の両面から, 魅力的な新素 材の開発が進むことに期待したい。

文 献

1) K. Sato, M. Aoki, M. Ogawa, T. Hashimoto, R. Noyori, J. Org. Chem., 61, 8310(1996)

2) R. Noyori, M. Aoki, K. Sato, Chem. Commun., 2003, 1977

3) (a) 内田博, 新井良和, 佐藤一彦, 千代健文 特開 2011078060; (b) 昭和電工ホームページ (http://www.sdk.co.jp/)

4) H. Toda, R. Imae, N. Itoh, Adv. Synth. Catal., 356, 3443(2014)

5) H. Lin, Y. Liu, Z.-L. Wu, Chem. Commun., 2011, 2610

6) U. E. Ukaegbu, A. Kantz, M. Beaton, G. T. Gassner, A. C. Rosenzweig, Biochemistry, 49, 1678(2010)

7) H. Lin, Y.-C. Liu, Z.-L. Wu, Bioresour. Bioprocess., 3, 10(2016)

(2018 年 3 月 28 日受理)

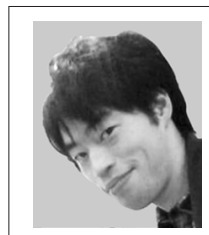

松田 豊 味の素株式会社バイオ・ファイン研究所 生体機能物質グループ 研究員 博士（工学）

〔所属グループ長〕杉木正之

〔経歴〕2013 年慶應義塾大学大学院基礎理工学専 攻後期博士課程単位取得退学（指導教官：中田雅 也教授)，味の素株式会社バイオ・ファイン研究所 機能材料グループ研究員を経て 2016 年 7 月より現職。〔受賞歴な ど〕第 4 回日本化学会関東支部大会学生講演賞。〔専門〕有機合成 化学, ケミカルバイオロジー。〔連絡先〕e-mail: yutaka_matsuda@ ajinomoto.com

Fig. 2 Bioproduction of epoxyalkane using SMO. 